\title{
Convergence and Differentials In State Investment Patterns
}

\author{
Robert Kirk*
}

\section{INTRODUCTION}

One of the issues that has confronted regional analysts is whether regional growth patterns are equilibrating or disequilibrating. Garnick and Renshaw have reviewed regional growth patterns, examined competing hypotheses about whether these patterns were equilibrating or disequilibrating, and speculated about whether the patterns would continue in the 1980's [3]. Evidence presented by Garnick and Renshaw to support the equilibrium hypothesis included the long-term trend toward equalization of per capita personal income among regions and rural-urban migration prior to 1970 from low to high income areas. Disequilibrium hypotheses emphasized the external costs imposed on sending regions arising from the tendency for the younger better-educated person to migrate, and the polarization arising from agglomeration economies.

This paper focuses on the equilibrium-disequilibrium issue by examining differentials in state manufacturing investment patterns. Two questions about these differentials are asked. Have state capital-labor ratios converged or diverged? What are determinants of interstate differentials in manufacturing investment?

\section{CONVERGENCE IN CAPITAL-LABOR RATIOS BY STATE}

Convergence in capital-labor ratios is an implication of the neoclassical growth model that has been widely used in regional growth theory [8]. For example, Smith's model which combines interstate factor movements with a neoclassical growth model implies convergence in state capital-labor ratios [9]. Given idential production functions and mobility of resources, variation among states in capital-labor ratios will result in labor flowing from low-wage to high-wage states (because the marginal productivity of labor in the low-wage states is low due to limited capital) and capital flowing from high-wage states to low-wage states (because the marginal productivity of capital in high-wage states is low due to relatively plentiful capital). As a result, capital-labor ratios by state are predicted to converge and the economic returns to homogenous resources will be the same among the states.

*Department of Economics, Indiana University at Indianapolis. 
In this paper, convergence of capital-labor ratios is measured by the coefficient of variation $-(\mathrm{CV}=\mathrm{s} / \overline{\mathrm{X}})$ where $\mathrm{CV}=$ coefficient of variation, $\mathrm{s}=$ sample standard deviation, and $\overline{\mathrm{X}}=$ sample mean. If the coefficient decreases over time, convergence is occurring. The measure of capital stock used is Browne's time-series estimates of manufacturing capital stock by state. ${ }^{1}$ These estimates are based on values from the Census of Manufactures and Annual Survey of Manufactures $[10,11]$. The sample consists of the 48 contiguous states. Since the figures on manufacturing investment in the Census include the replacement of used-up capital equipment and structures and, therefore, tend to overstate the increase in capital stock, they were adjusted using decay schedules developed by the Bureau of Labor Statistics, Office of Economic Growth. The labor measure is the number of production worker manhours provided by the Census of Manufactures. It assumes that the true labor input is proportional to the number of hours worked.

In Table 1, coefficients of variation for capital-labor ratios are shown for selected years. The years (1957, 1960, 1969, and 1973) were chosen because they were peak years in the business cycle, and 1976 was the last year for which capital stock was estimated by Browne. Peaks were chosen, rather than troughs, because when unanticipated inventory accumulation occurs the process of adjustment involves initially the variable inputlabor-first in reduced hours of work and then in reduced levels of employment.

Since 1960, the coefficients have decreased implying convergence in capital-labor ratios. This empirical test for convergence is support for the neoclassical growth model and the idea that there are equilibrating processes in operation in the economy.

\section{INTERSTATE DIFFERENTIALS IN INVESTMENT}

Regional investment patterns have been studied by Browne with Mieszkowski and Syron [1]. Their results include: (1) in the seventies at the regional level the growth in capital returned to the low rates of the early sixties with the exception of the South; (2) there was significant variation among the states within the four large regions; and (3) variation in growth

TABLE 1.

Coefficients of Variation in Capital-Labor Ratios by State for Selected Years.

\begin{tabular}{cc}
\hline Year & $\begin{array}{c}\text { Coefficient } \\
\text { of Variation }\end{array}$ \\
\hline 1957 & 57.14 \\
1960 & 62.45 \\
1969 & 55.98 \\
1973 & 51.43 \\
1976 & 42.45 \\
\hline
\end{tabular}


in capital was not associated with industry mix. Therefore, to explain interstate variation in investment, they used variables suggested by location theory in their pooled analysis for the years, 1959-76. The cost factors and other variables explained 33 percent of the variation in state per capita net investment.

In this paper, to predict interstate differentials in investment via a linear regression model, a variety of factors important to the location of manufacturing investment was considered. These factors were suggested by location theory and surveys of state manufacturers' associations [2,7]. The state associations were asked to rank factors considered to be conducive to the attractiveness of one state's business climate relative to another's. The factors included state fiscal variables such as state and local taxes, state spending growth versus state income growth, state debt, and state spending; energy cost per million BTUs; labor cost variables such as labor union membership, average weekly manufacturing wage, manhours lost per year, workmen's compensation insurance rate, average unemployment benefits paid, and maximum weekly payment for disability; and a quality of life variable such as state disbursements for highways per highway mile. Partial correlation analysis of these variables showed high intercorrelation among some of the variables.

The variables used in the model were:

Dependent variable:

$\mathrm{N}_{\mathrm{i}} / \mathrm{P}_{\mathrm{i}}=$ net investment per capita in state $\mathrm{i}$

Independent variables:

$\mathrm{K}_{\mathrm{i}} / \mathrm{P}_{\mathrm{i}}=$ manufacturing capital stock per capita in state $\mathrm{i}$

$\mathrm{Pd}_{\mathrm{i}} / \mathrm{Pd}_{\mathrm{US}}=$ labor productivity in state $\mathrm{i}$ relative to labor productivity in the U.S., in index form

$\mathrm{U}_{\mathrm{i}} / \mathrm{N}_{\mathrm{i}}=$ union membership as a percent of total nonagricultural employment in state $\mathrm{i}$

$\mathrm{E}_{\mathrm{i}} / \mathrm{E}_{\mathrm{US}}=$ manufacturing energy cost per million BTUs in state $\mathrm{i}$ relative to manufacturing energy cost per million BTUs in the U.S., in index form

$\mathrm{YP}_{\mathrm{i}} / \mathrm{YP}_{\mathrm{US}}=$ percent change in income potential, 1970-74, in state $\mathrm{i}$ relative to percent change in income potential, 1970-74, in the U.S., in index form. 
The dependent variable is net investment per capita. The regression analysis is cross-sectional with 1972 as the year of analysis. However, since investment occurs with a lag and a representative lag is eight quarters, the dependent variable is net investment (change in capital stock) over the period, 1972-74, adjusted by the 1972 population [5]. The net investment is divided by population to correct for heteroscedasticity. In cross-sectional analysis the error terms associated with states having large manufacturing sectors will probably have greater variance than those with small sectors.

The first independent variable, capital stock per capita, is a measure of agglomeration economies. The sign of the regression coefficient is expected to be positive. The capital stock variable is converted to a per capita basis to correct for correlation of absolute levels of capital stock with size of state population.

The second independent variable, a labor productivity index, is a measure of labor cost. It is assumed that money wages exhibit less variation among states than labor productivity because of the existence of nationwide collective bargaining in key manufacturing industries and the effect of interstate labor mobility on the reduction of wage differentials. Therefore, labor productivity would exhibit more variation than wages. Some support for this assumption is given by the coefficient of variation-for the wage index (11.99) and the productivity index (14.24). The labor productivity index was developed by Miller, and uses the U.S. as the norm [6]. The index is value added divided by the number of production worker manhours. Value added was selected over value of shipments as an output measure because value added controls for variations in the degree of vertical integration. The sign of the regression coefficient is expected to be positive-higher labor productivity means lower resource cost, higher expected profit, and higher net investment.

The third independent variable, labor union membership as a percent of total employment, is a resource cost variable. Labor union membership is included to indicate the degree of unionization and the relative impact of the unionized sector on labor relations and legislative influence. From the point of view of the firm making the investment decision, the firm would want to select a location in which the percent was minimized. ${ }^{2}$ Therefore, the sign of the regression coefficient is expected to be negative.

The fourth independent variable, manufacturing energy cost per million BTUs, is a cost of energy variable and is included in the analysis to determine its importance to investment-although the data used are for 1972. The sign of the regression coefficient is expected to be negative-the higher the energy cost in the state relative to the U.S., the less attractive the state would be for investment.

The fifth independent variable, an income potential index, is a measure of access to final markets. The income potential in a state $i$ is: 


$$
P_{i}=\sum_{j=1}^{n}\left(Y_{j} / d_{i j}\right)(i=1, \ldots, n)
$$

where:

$$
\begin{aligned}
& P_{i}=\text { income pot ntial in state } i \\
& Y_{j}=\text { personal income in state } j \text {, and } \\
& d_{i j}=\text { distance from state } i \text { to state } j
\end{aligned}
$$

Thus, an increase in the measure indicates that the income of persons at a distance from the state has become greater and, therefore, the state has a greater potential market in which to sell. Giarratani and Socher have computed measures of income potential for 1970 and 1974 for each of the states [4]. They show that the income potential increased at a greater rate for the 34 energy-producing states than for the 14 nonproducing states. The change in income potential, 1970-74, in the state relative to the change in income potential, 1970-74, for the U.S. is used as a measure of the shift in market access. The sign of the regression coefficient is expected to be positive-the higher the index, the greater the investment.

\section{REGRESSION RESULTS}

The model is specified to be the following:

$$
\mathrm{N}_{\mathrm{i}} / \mathrm{P}_{\mathrm{i}}=\mathrm{b}_{1}+\mathrm{b}_{2} \mathrm{~K}_{\mathrm{i}} / \mathrm{P}_{\mathrm{i}}+\mathrm{b}_{3} \mathrm{Pd}_{\mathrm{i}} / \mathrm{Pd}_{\mathrm{US}}+\mathrm{b}_{4} \mathrm{U}_{\mathrm{i}} / \mathrm{N}_{\mathrm{i}}=\mathrm{b}_{5} \mathrm{E}_{\mathrm{i}} / \mathrm{E}_{\mathrm{US}}+\mathrm{b}_{6} \mathrm{YP}_{\mathrm{i}} / \mathrm{YP}_{\mathrm{US}}
$$

The regression results are in Table 2:

The coefficients of the capital stock, labor productivity, and labor union variables are statistically significant at the five percent level and have the expected signs. The coefficients for the energy cost and income potential variables are not statistically significant. The elasticities at the means suggest that changes in net investment per capita are most responsive to

TABLE 2.

Equation for Net Manufacturing Investment Per Capita, 1972

\begin{tabular}{crcrc}
\hline Coefficient & \multicolumn{1}{c}{ Value } & t statistic & \multicolumn{1}{l}{ Beta } & Elasticity at means \\
$\mathrm{b}_{1}$ & -6.72 & -0.95 & & \\
$\mathrm{~b}_{2}$ & .07 & $5.37^{*}$ & .64 & .74 \\
$\mathrm{~b}_{3}$ & 1.21 & $2.59^{*}$ & .28 & 1.04 \\
$\mathrm{~b}_{4}$ & -4.09 & $-4.71^{*}$ & -.62 & -.83 \\
$\mathrm{~b}_{5}$ & -26.04 & -.96 & -.11 & - \\
$\mathrm{b}_{6}$ & .41 & 1.10 & .14 & - \\
\hline
\end{tabular}

*statistically significant at the 5 percent level

$\mathrm{R}^{2}=.49$; Durbin-Watson statistic $=1.90$

Haitovsky multicollinearity test $=27.69 ; \mathrm{n}=48$. 
changes in labor productivity (a one percentage point increase in labor productivity will induce a 1.04 percentage point increase in net investment), followed by union membership (a one percent increase in the percent of the nonagricultural employment that is unionized will induce a .83 percent decrease in net investment), ${ }^{3}$ and agglomeration economies (a one percent increase in capital stock per capita will induce a .74 percent increase in net investment). There appears to be no problem with multicollinearity with the test being statistically significant. Also, the DurbinWatson statistic indicates that spatial autocorrelation is not a problem. The equation explains 49 percent of the variation in the dependent variablean improvement over Browne's model using a pooled analysis.

\section{GONCLUSIONS}

Empirical evidence has been presented on two questions about regional change. One is the question: Are regional investment patterns equilibrating or disequilibrating? Under the equilibrating hypothesis, capital-labor ratios are expected to converge. The evidence presented above is that convergence occurred during the period, 1960-76. The other question is: What determines interstate differentials in manufacturing net investment? The policy relevance of the analysis of these determinants is suggested by the magnitude of the elasticity coefficients with the labor cost variable, as measured by relative labor productivity and percent of the nonagricultural employment that is unionized, being the most important. This conclusion is consistent with Browne's results. Given the responsiveness of net investment to relative labor productivity, further analysis of the determinants of interstate differentials in labor productivity is warranted.

Although primary attention nationally has been given to the macroeconomic effects of the Economic Recovery Tax Act of 1981, the spatial effects are important to regional analysts. This paper contributes to our understanding of the spatial dimension of the investment process. The beta coefficients in the regression analysis indicate that investment would be expected to occur where there already exists high capital stocks per capita and the percent of the labor force that is unionized is low. States having relatively high capital stocks per capita include those in the East North Central Region (Ohio, Indiana, Illinois, and Michigan), the MidAtlantic Region (New Jersey, Pennsylvania, and Delaware), West Virginia, North Carolina, South Carolina, Louisiana, and Texas. On the other hand, states with relatively low percents of the labor force that is unionized are generally in the South and the West North Central Region.

The coefficients for the energy and income potential index variables may be significant at the industry level. Therefore, further research at an industry-disaggregated level is warranted. 


\section{FOOTNOTES}

${ }^{1}$ Lynn Browne, Federal Reserve Bank of Boston, provided the unpublished estimates of capital stock by state. I express appreciation for these estimates.

${ }^{2}$ Alexander Grant \& Company (Chicago) has, in cooperation with the Conference of State Manufacturers' Associations (COSMA), ranked the relative attractiveness of the business climates of the $\mathbf{4 8}$ contiguous states of the U.S. Labor union membership was the "attractiveness" factor that received the third highest weighting behind state and local taxes and energy cost per million BTUs. In the survey, low labor union membership as a percent of total labor force was associated with high attractiveness.

${ }^{3}$ Survey response from manufacturers ranked state and local taxes most frequently in evaluating desirable business climates. In this paper, net investment per capita was highly negatively correlated with per capita state and local tax revenues and, therefore, the correlation supports the survey responses. However, tax revenues were highly positively correlated with labor union membership and, therefore, tax revenues were excluded from the regression model to avoid multicollinearity.

\section{REFERENCES}

1. Browne, Lynn E. with Mieszkowski, Peter and Syron, Richard F., "Regional Investment Patterns," New England Economic Review (July/August 1980), p. 11.

2. "Business Climates," a study by Alexander Grant \& Company in cooperation with the Conference of State Manufacturers' Associations (Chicago, 1981).

3. Garnick, Daniel and Renshaw, Vernon, "Competing Hypotheses on the Outlook for Cities and Regions: What the Data Reveal and Conceal," (Bureau of Economic Analysis, U.S. Department of Commerce, 1980), unpublished paper.

4. Giarratani, Frank and Socher, Charles F., "The Pattern of Industrial Location and Rising Energy Prices," in Miernyk, William H., Regional Impacts of Rising Energy Prices (Cambridge, Ballinger, 1978), pp. 110-11.

5. Jorgenson, Dale W., "Econometric Studies of In- vestment Behavior: A Survey," Journal of Ecomomic Literature Vol. IX, No. 4 (December 1971), p. 1135.

6. Miller, Edward, American Productivity Center, Houston, Texas, calculations provided by private correspondence.

7. Perloff, Harvey S., Dunn, Edgar S., Lampard, Eric E., and Muth, Richard F., Regions, Resources, and Economic Growth (Lincoln, University of Nebraska Press, 1960), pp. 75-86.

8. Richardson, H. W., Regional Growth Theory (New York, Halsted, 1973), pp. 22-29.

9. Smith, D. M., "Neoclassical Growth Models and Regional Growth in the U.S.," Journal of Regional Science Vol. 15, No. 2, (1975), pp. 165-181.

10. U.S. Bureau of the Census, Census of Manufactures, selected years.

11. U.S. Bureau of the Census, Annual Survey of Manufactures, selected years. 